\title{
Armenia's Military Aggression Against Azerbaijan: Violation of the Rights of Captives and Hostages
}

\section{Ermenistan'ın Azerbaycan'a Karşı Askeri Saldırısı: Esir ve Rehinelerin Haklarının İhlali}

\author{
Ramile Behlül Kızı Dadaşova ${ }^{1}$ [C
}

${ }^{1}$ Corresponding author/Sorumlu yazar: Ramile Behlül Kızı Dadaşova (Assoc. Prof. Dr.), Azarbaijan National Academy of Sciences, Division of Social Sciences, Institute of the Caucasian Studies, Baku, Azerbaijan Republic E-mail: dadashova.ramila@rambler.ru ORCID: 0000-0002-2376-5941

Submitted/Başvuru: 19.11.2019 Revision Requested/Revizyon Talebi: 18.02.2020

Last Revision Received/Son Revizyon: 04.03.2020

Accepted/Kabul: 05.03.2020

Published Online/Online Yayın: 30.03.2020

Citation/Atıf: Dadashova, Ramile Behlül Kızı. "Armenia's Military Aggression Against Azerbaijan: Violation Of The Rights Of Captives And Hostages.", Avrasya Incelemeleri DergisiJournal of Eurasian Inquiries 9, 1 (2020): 55-73. https://doi.org/10.26650/jes.2020.004

\begin{abstract}
International documents are important mechanism for protecting the rights of citizens in armed conflicts, and these documents can help the UN Security Council to protect human rights. International humanitarian law is reflected in three documents: 1907 The Hague Conventions respecting the Laws and Customs of War on Land and its annex, Protocol Additional to the Geneva conventions of 12 August 1949, and 1977 Geneva conventions relating to the Protection of Victims of International Armed Conflicts (Protocol I) and other international law's documents reflecting the principle of respect for human rights. These international conventions have repeatedly been violated by Armenia, which is a member of the UN. According to the information of the State Commission of the Republic of Azerbaijan on Prisoners of War, Hostages and Missing Persons dated February 1, 2019, the number of missing persons registered by the State Committee is 3,888. Most of these people were killed in Armenian captivity, committed suicide because of torture, illness, and the rest were hidden by Armenians and being used in heavy physical work in Armenia and occupied Azerbaijani territories. As a universal organization, the UN Security Council can force Armenia to comply with international humanitarian law. Referring to resolutions adopted by the UN Security Council, the International Criminal Tribunal for Khojaly should be established and criminals should be punished. The International Court of Justice Commission can be established to regulate legal matters concerning criminals and this Commission should cooperate closely with the International Court of Justice, the Human Rights Council, the Compensation Commission, and conduct joint investigations.
\end{abstract}

Keywords: Geneva conventions, captives, Khojaly genocide, hostages, international humanitarian law

\section{öz}

Uluslararası belgeler, vatandaşların silahlı çatışmalardaki haklarını korumak için önemli bir mekanizmalar olup ve bu belgeler Güvenlik Konseyi'nin insan haklarını korumasına yardımcı olabilir. Uluslararası İnsancıl Hukuku ağırlıklı olarak üç belgede yansıtılmaktadır: 1907 Kara Harbinin Kanunları ve Adetlerine Dair Lahey Sözleşmesi ve ekleri, 12 Ağustos 1949 tarihli Cenevre sözleşmelerine 
ek Protokol ve 1977 tarihli Uluslararası Silahlı Çatışmalarda Mağdurların Korunmasına Dair Cenevre sözleşmeleri (Protokol I) ve diğer uluslararası hukukun insan haklarına saygı ilkesini yansıtan diğer belgeleri. Söz konusu uluslararası sözleşmeler, BM üyesi olan Ermenistan tarafından defalarca ihlal edilmiştir. Savaş Esirleri, Rehinler ve Kayıp Kişilerle ilgili Azerbaycan Cumhuriyeti Devlet Komisyonu'nun 1 Şubat 2019 tarihli raporuna göre kayıp kişi sayısı 3888 kişidir. Bu insanların çoğu Ermeni esareti altında öldürülmüş, işkenceye, hastalıklara dayanamayarak intihar etmiş, geri kalanlar Ermeniler tarafından esir tutulmakta ve Ermenistan'da ve Azerbaycan'ın işgal altındaki bölgelerinde ağır fiziksel işlerde kullanılmaktadır. Evrensel bir örgüt olarak BM Güvenlik Konseyi Ermenistan'ı uluslararası insancıl hukuka uymaya zorlayabilir. BM Güvenlik Konseyi tarafından alınan kararlara atıfta bulunarak, Hocalı için Uluslararası Ceza Mahkemesi kurulmalı ve suçlular cezalandırılmalıdır. Suçlularla ilgili yasal hususları düzenlemek için Uluslararası Adalet Divanı Komisyonu kurulabilir ve bu Komisyon Uluslararası Adalet Divanı, İnsan Hakları Konseyi, Tazminat Komisyonu ile yakın işbirliği yaparak ve ortak soruşturmalar yürütebilir.

Anahtar kelimeler: Cenevre sözleşmeleri, esirler, Hocalı soykırımı, rehineler, uluslararası insancıl hukuk

\section{GENIŞLETILMIŞ ÖZET}

Uluslararası ilişkiler uluslararası hukuk prensiplerinin gerçekleşdirilmesi ile balanslaşdırlıyor. Uluslararası insani hukuk 1907 yılı Kara Savaşı kanunları ve adetleri hakkında dördüncü Haaga Sözleşmesi, 194912 Ağustos tarihli Savaş sırasında sivil halkın korunmasına ilişkin dördüncü Cenevre Sözleşmesi, 1977 Uluslararası silahlı çatı̧̧ma kurbanlarının korunması konusunda Cenevre Sözleşmesi'ne I Ek protocol gibi bir çok belgelerde belirtiliyor. İnsan haklarına saygı prensipi ilk kez olarak BM'nin Anayasasında bildirilen şekilde tespit edilmiş, daha sonra insanlığa büyük kayıplar veren soykırımın önlenmesi için uluslararası işbirliğinin gerekliliğini dikkate alan BM Genel Kurulu 1948 yılı 9 Aralık tarihte Soykırımı cinayetinin önlenmesi ve ona göre cezalandırma hakkında sözleşme kabul etti. Uluslararası belgeler, silahlı çatışmalarda vatandaşların haklarını korumak için önemli bir mekanizmadır ve bu belgeler BM Güvenlik Konseyi'nin insan hakların korumasına yardımcı olabilir. İnsan haklarına saygı prensipi modern uluslararası hukukun temel prensiplerinden olsa da yukarıda belirtilen uluslararası belgelerle birlikte, birçok sözleşme Ermenistan tarafından ihlal edildi. Azerbaycan topraklarının işgali sırasında esir alınan binlerce kişi Ermenistan'da saxlanılıyor. Birleşmiş Milletler temsilcileri Ermenistan'da rehin ve esir tutulan insanlara vahşice işkenceler verilmesine tanık olmuşlardı. Savaş Esirleri, Rehinler ve Kayıp Kişilerle ilgili Azerbaycan Cumhuriyeti Devlet Komisyonu'nun 1 Şubat 2019 tarihli raporuna göre kayıp kişi sayısı 3888 kişidir. Bu insanların çoğu Ermeni esirliğinde öldürülmüş, işkenceye, hastalıklara dayanamayarak intihar etmiş, geri kalanlar Ermeniler tarafindan saklanmakta ve Ermenistan'da ve Azerbaycan'ın işgal altındaki bölgelerinde ağır fiziksel işlerde kullanılmaktadır. Esir ve rehinelerin sayısı uluslararası kuruluşlardan gizlenir. Araştırmalara göre Ermenistan’ın esaretinde 553 Azerbaycan vatandaşının öldüğü tespit edildi. Esir ve kayıplara düşmüş, rehin alınmış vatandaşlarla ilgili Devlet Komisyonu uluslararası hukuk normlarına uygun olarak uluslararası kuruluşlara, Uluslararası Kızıl Haç Cemiyeti'ne, esir ve rehinelerin serbest bırakılması, kayıplara düşmüş kişilerin arayışı uluslararası çalışma grubuna işkencelerle ilgili olguları takdim etseler de, Uluslararası Kızıl Haç Cemiyeti ve diğer 
uluslararası kuruluşlar kayıplara düşenlerin kaderi ile ilgilenmiyorlar. Uluslararası kuruluşlar, faaliyetlerini yalnızca teknik görevlerle sınırlandırmıştır.

Hocalı soykırımına kadar Haziran-Aralık 1991'de Ermenistan silahlı küvvetleri, Meşeli, Cemilli, Tuğ, Imaret-Garvend, Sırhavend, Umudlu, Kerkicahan ve Karabă̆'ın dağlık kesiminde 30'dan fazla yerleşim yerinde soykırım yaptı. Ocak-Şubat 1992'de Garadaglı, Gaybalı, Malibeyli, Aşağı Guşçular, Yukarı Guşçular köyleri işgal edildi ve yakıldı. 25 Şubat 26'sına geçen gece yüzyılın büyük trajedisi Hocalı soykırımı yaşandı. Ermeniler Hankendi'ndeki Rusya'ya ait 366. motorize alayının katılımıyla Hocalı'yı işgal ettiler. Azerbaycanlı katliamında 613 kişi vahşice işkencelerle katledildi, 487 kişi yaralandı (Bunlardan 76'sı çocuktu), 1275 kişi esir alındı, 8 aile imha edildi, şehir yakıldı, 25 çocuk her iki ebeveynini, 130 çocuk bir ebeveynin kaybetti. Öldürülen 106 kişiyi kadın, 63 kişiyi çocuktu,

70 kişi yaşlıydı. Saldırı sırasında 366. alayın komutanları Seyran Ohanyan, Yevgeni Nabokix, Genelkurmay Başkanı Valeri Çitçyan, alayın askeri personelin Slavik Arutyunyan, Andrey Şixanyan, Sergey Beqlaryan, Movses Akopyan, Grigori Kisebekyan, Vaçik Mirzoyan, Vaçagan Ayriyan, Alexander Ayrapetyan, Ermeni silahlı birlikleri üyelerinden Fayans Petrosyan, Seyran Tumasyan, Valera Grigoryan, Hankendi şehir içişleri şubesinin reisi işlemiş Armo Abramyan, Esgeran bölge içişleri şubesinin reisi işlemiş Mavra Gukasyan, onun yardımcısı Şaqen Barseqyan, Dağlık Karabağ'da Ermeni halk cephesinin Başkanı olmuş Vitali Balasanyan, Hankendi şehir hapishanesinin reisi işlemiş Serj Koçaryan ve başkaları Azerbaycanlı soykırımında aktif katılmıştır.

Hocalı soykırımı Ermenistan hükümeti tarafından uygulandı. Robert Kocharyan ve Serj Sarkisyan hükümeti, Ermenistan'da devlet düzeyinde Azerbaycanlılara karşı kitlesel terör eylemleri gerçekleştirdi. İngiliz yazar ve gazeteci Thomas de Waal (Dağlık Karabağ sorununun uzmanı) ile yaptığı röportajda Azerbaycan sivillerinin öldürüldüğünü

itiraf eden Serj Sarkisyan, Hocalı soykırımı ile ilgili şunları söyledi: “Azerbaycanlılar Ermenilerin sivil halka karşı katliam yapmayacağını düşünmekteydiler. Biz bunu azerbaycanlılara şaka yapmadığımızı göstermek amacıyla ibret olsun diye yaptık".

Ermenistan 1989 tarihli Çocuk Hakları Sözleşmesi'ni de ihlal etmektedir.

Ermenistan'ın Azerbaycan'a yönelik askeri saldırısı sonucunda 195 Azerbaycanlı çocuk Ermeni silahlı kuvvetleri tarafından öldürüldü. 1988-1989 yıllarında Ermenistan ’a yapılan etnik temizleme sonucunda 216 Azerbaycanlı öldürüldü, bunlardan 23'ü çocuk idi.

Ateşkesi görmezden gelen Ermenistan silahlı kuvvetleri, son zamanlarda da masum sivilleri esir almakda devam ediyor. Örneğin, 11 Temmuz 2014'te Rusya vatandaşı Azerbaycanlı Dilgam Asgarov ve Azerbaycan vatandaşı Shahbaz Guliyev Azerbaycan`ın Kalbajar bölgesindeki Shaplar köyündeki akrabalarının mezarlarını ziyaret ederken Ermenistan silahlı kuvvetleri tarafından esir alındı. Azerbaycan vatandaşı Hasan Hasanov öldürüldü.

Dünya toplumu, Ermenistan'ın esir ve rehinelerle ilgili uluslararası hukuka uymadığı gerçeğine karşı ne gibi önlemler alabilir? İlk olarak, insan hakları ve temel özgürlüklere saygı 
prensiplerini belirleyen evrensel bir örgüt olarak BM Güvenlik Konseyi Ermenistan'ı uluslararası insancıl hukuka uymaya zorlayabilir. İkinci olarak, BM Güvenlik Konseyi tarafından alınan kararlara atıfta bulunarak, Hocalı için Uluslararası Ceza Mahkemesi kurulmalı ve suçlular cezalandırılmalıdır. Üçüncüsü, suçlularla ilgili yasal hususları düzenlemek için Uluslararası Adalet Divanı Komisyonu kurulabilir ve bu Komisyon Uluslararası Adalet Divanı, İnsan Hakları Konseyi, Tazminat Komisyonu ile yakın işbirliği yaparak ortak soruşturmalar yürütebilir. Uluslararası ilişkilerin istikrarlı gelişmesi için uluslararası hukuk normlarına devletleri uymaya zorlamak, suçlu tarafa yaptırımların uygulanması ve diger yönünden BM sistemi uluslararası anlaşmazlıkların hukuk normlarına uygun düzene düşürülmesine yardımcı mekanizmaya sahiptir. Küreselleşme sürecinde uluslararası güvenlik sorunlarının önlenmesi, dengeli uluslararası ilişkiler sistemini geliştirmek için insan haklarının ihlalinden önü alınmalı, BM'nin kabul ettiği uluslararası sözleşmelere, belgelere takip edilmelidir.

Dördüncüsü, savaş esirleri ve rehineler serbest bırakılmalı, soruşturma sonuçlarına göre suçlular cezalandırılmalıdır. 


\section{Introduction}

International humanitarian law is reflected in three documents: 1907 The Hague Conventions respecting the Laws and Customs of War on Land and its annex, Protocol Additional to the Geneva conventions of 12 August 1949, and 1977 Geneva Conventions relating to the Protection of Victims of International Armed Conflicts (Protocol I) and other international law documents reflecting the principle of respect for human rights. International documents are an important mechanism for protecting the rights of citizens in armed conflicts, and these documents can help the UN Security Council to protect human rights. However, along with the aforementioned international documents, many other conventions including the European Convention for the Protection of Human Rights and Fundamental Freedoms, the Convention on the Prevention and Punishment of the Crime of Genocide on 9 December 1948, the International Convention Against the Taking of Hostages adopted by the General Assembly of the United Nations on 17 December 1979, the Convention against torture and other cruel, inhuman or degrading treatment adopted by the General Assembly of the United Nations on 10 December 1984, the Convention on the Elimination of All Forms of Discrimination against Women, the 1989 Convention on the Rights of the Child, directly related to respect for human rights have repeatedly been violated by Armenia, which is a member of the UN. As a result of Armenia's military aggression against Azerbaijan, more than 20,000 Azerbaijani citizens were killed, 100,000 were injured and 50,000 were disabled. More than 1 million people, including more than 200,000 children, have been subjected to torture and inhumane treatment in the occupied territory and have been forced out of their homes and become refugees in their own land. According to the information of the State Commission of the Republic of Azerbaijan on Prisoners of War, Hostages, and Missing Persons dated February 1, 2019, the number of missing persons registered by the State Committee is 3,888. Of these, 3170 are military men, 718 are civilians, 71 children, 266 women, and 326 old people ${ }^{1}$.

\section{Determination of the rights of captives and hostages in international documents}

The principle of respect for human rights was first formulated in the United Nations Charter, then it was detailed in several important international documents, including the Universal Declaration of Human Rights $1948^{2}$. Paragraph 3, Article 1 of the UN Charter states that, one of the aims of the UN is to achieve international cooperation in the resolution of economic, cultural, and humanitarian problems worldwide and to respect all human rights and liberties regardless of race, gender, language, or religion and to play the central role for regulation of the actions of nations in the direction of achieving these common goals ${ }^{3}$. Article 55 reaffirms

1 State Commission of the Republic of Azerbaijan on Prisoners of War, Hostages and Missing Persons. http:// www.human.gov.az/en/view-page/27/War\%2C+hostages+and+missing+ persons

2 The Universal Declaration of Human Rights http://www.un.org/en/udhrbook/pdf/udhr_booklet_en_web.pdf

3 Charter of the United Nations and Statute of the İnternational Court of Justice. San Francisco, 1945. https:// treaties.un.org/doc/publication/ctc/uncharter.pdf, 3 . 
support of the UN for respect of human rights and freedoms ${ }^{4}$. Article 56 states: "All Members pledge themselves to take joint and separate action in cooperation with the Organization for the achievement of the purposes set forth in Article 55"5. The principle of respect for human rights was reflected in the OSCE Helsinki Final Act as an independent principle of international law. In accordance with this principle, States should respect human rights and should support it internationally ${ }^{6}$.

On December $20^{\text {th }}, 2004$, the United Nations General Assembly adopted Resolution 59/189 "Missing persons", through which it urges those States which take part in armed conflicts to adopt all such measures as may be appropriate to prevent the disappearance of persons in connection with said conflict and to ascertain the whereabouts of people who are unaccounted for in connection with said situation. In addition, this resolution reaffirmed the right of families to know the fate of members unaccounted for in connection with armed conflicts ${ }^{7}$. There are special provisions in international humanitarian law about missing persons. The European Convention on Human Rights, particularly, Articles 2, 3, 5, 8, 10, and 13, provides the right to know the number of missing persons ${ }^{8}$. There are similar provisions in General Assembly Resolution Number 61/155 of 14 February $2007^{9}$ and 63/183 ${ }^{10}$ of 18 March 2009.

Article 19 of the Fourth Geneva Convention relative to the Protection of Civilian Persons in Time of War of 1949 envisages the simplification of the search of missing people by conflicting parties ${ }^{11}$. Particularly, Article 33 of the I Additional Protocol to that convention was specifically devoted to this problem. When the war ends, conflicting parties must look for those who are missing, and the opposite party must provide all necessary information for the search of such persons ${ }^{12}$. As reported in Article 138 of the Fourth Geneva Convention relative to the protection of civilian persons in time of war of 12 August 1949, a report about

4 Charter of the United Nations and Statute of the İnternational Court of Justice....., 11-12. https://treaties.un.org/ doc/publication/ctc/uncharter.pdf

5 Charter of the United Nations and Statute of the İnternational Court of Justice......, 12. https://treaties.un.org/ doc/publication/ctc/uncharter.pdf

6 Conference on Security and Cooperation in Europe Final Akt. Helsinki, 1975. http://www.osce.org/helsinkifinal-act?download=true, 6-7.

7 Participation in International Humanitarian Law Treaties and Their National Implementation. Achievements and activities in the countries of the Americas in 2005. Document prepared by the International Committee of the Red Cross (ICRC) for the information of the Member States of the Organization of American States. January, 2006. https://www.icrc.org/en/doc/assets/files/other/informe_202005_eng.pdf, 12.

8 European Convention on Human Rights. http://swww.echr.coe.int/Documents/Convention_ENG.pdf 6-8, 11; Сборник документов ООН по армяно-азербайджанскому нагорно-карабахскому конфликту [UN's Documents on the Armenian-Azerbaijani Nagorno-Karabakh Conflict], Баку, Министерство Иностранных Дел, 2009, 349.

9 Resolution adopted by General Assembly 61/155, http://mfa.gov.az/files/file/UN

10 Resolution adopted by General Assembly 63/183. http://mfa.gov.az/files/file/UN

11 The Geneva Conventions of 12 August 1949. IV Geneva Convention relative to the Protection of Civilian Persons in Time of War. Geneva, International Committee of the Red Cross 1958, 154-156.

12 Protocol Additional to the Geneva Conventions of 12 august 1949, and relating to the Protection of victims of international armed conflicts (protocol I), of 8 june 1977. https:/www.icrc.org/en/doc/assets/files/other/ icrc_002_0321.pdf, 28. 
detained people or about those who died during the time of detention shall be provided and the removal of bodies is to be organized ${ }^{13}$. Article 5 of the Universal Declaration of Human Rights of December 10, 1948 states: " No one shall be subjected to torture or to cruel, inhuman or degrading treatment or punishment"14.

Article 4 of the 1989 Convention on the Rights of the Child states that in order to protect the civilian population during armed conflicts, and to comply with international law, and to ensure removal of them from conflict zones, States Parties shall take all possible measures: "Governments have a responsibility to take all available measures to make sure children's rights are respected, protected and fulfilled. When countries ratify the Convention, they agree to review their laws relating to children. This involves assessing their social services, legal, health, and educational systems, as well as levels of funding for these services. Governments are then obliged to take all necessary steps to ensure that the minimum standards set by the Convention in these areas are being met. They must help families protect children's rights and create an environment where they can grow and reach their potential. In some instances, this may involve changing existing laws or creating new ones. Such legislative changes are not imposed, but come about through the same process by which any law is created or reformed within a country. Article 41 of the Convention points out that when a country already has higher legal standards than those seen in the Convention, the higher standards always prevail"15.

The information is transmitted directly through The International Committee of the Red Cross (ICRC) and its central information agency or from the conflicting parties. However, Armenia hides the number of missing persons from the ICRC. In resolution 1553 of the Parliamentary Assembly of the Council of Europe (PACE) in November 2007, stated that the parties were required to share the number of missing persons during an armed conflict but Parliament was concerned about the confidentiality of missing persons and that 4,499 Azerbaijanis were missing during the Nagorno-Karabakh conflict ${ }^{16}$. Special provisions apply with regard to missing persons. Article 26 of the Geneva Convention IV provides that each party to the conflict shall facilitate inquiries made by members of families dispersed because of war, with the object of renewing contact with one another and of meeting, if possible. It shall encourage, in particular, the work of organizations engaged in this task provided they are acceptable to it and conform to its security regulations ${ }^{17}$. On 17 December 2018, with

13 Geneva convention relative to the protection of civilian persons in time of war of 12 august 1949, 58. http:// www.un.org/en/genocideprevention/documents/atrocity-crimes/Doc.33_GC-IV-EN.pdf

14 The Universal Declaration of Human Rights. http://www.un.org/en/udhrbook/pdf/udhr_booklet_en_web.pdf, 12.

15 Fact sheet: A summary of the rights under the Convention on the Rights of the Child. P.1.https://www.unicef. org/crc/files/Rights_overview.pdf; Конвенция ООН; конвенция о правах ребенка. М.: РИОР, $2006,17$.

16 Сборник документов ООН по армяно-азербайджанскому нагорно-карабахскому конфликту [UN's Documents on the Armenian-Azerbaijani Nagorno-Karabakh Conflict]..... 349.

17 IV Geneva Convention relative to the protection of civilian persons in time of war of 12 august 1949. http:// www.un.org/en/genocideprevention/documents/atrocity-crimes/Doc.33_GC-IV-EN.pdf, 178-179. 
the initiative of Azerbaijan, the Resolution on Missing Persons A/RES/73/178 was adopted through consensus at the plenary session of the UN General Assembly ${ }^{18}$. Sixty-two countries joined the document as co-authors. The main goal of the resolution, put forward every two years by Azerbaijan is to increase attention to the problem of missing persons in the world as a result of armed conflicts.

The countries of the resolution are urged to respect and follow the articles of international humanitarian law, to take all necessary measures to prevent missing people in situations of armed conflict, to search for missing persons, including to cooperate, in accordance with international obligations, in order to clarify the fate of those missing. The resolution reiterates the rights of families of missing persons to get information about the fate of their loved ones. The resolution calls on states to pay special attention to the issue of children missing in armed conflicts. The resolution includes a call to submit a detailed report with practical recommendations for its implementation at the 75th session of the UN General Assembly (2020) and the respective session of the UN Human Rights Council ${ }^{19}$.

Armenians violated international law by torturing civilians along with military prisoners, brutally beat, insulted, and turned them into objects of sale and, in most cases, did not return them after getting a large amount of money for their return, killed them, sold their internal body organs or did experiments on them ${ }^{20}$. Previous investigations of the State Commission proved that only 69 Azerbaijan citizens were released from captivity via ransom. These are not the only known facts:

- In front of 15 year old Nazakat Mamadova, Armenian servicemen were horribly tortured. Her father had his ears cut off, her mother could not tolerate the threats and lost her mind, and later the girl was sold to her family members;

- Nazarov Agshin Najmi Okhlu was captured by Armenian troops, during the occupation of Lachin town in 1992. In October 23, 1993, an Armenian servicemen, by the name Aram, sold Okhlu to his family for 7.5 million Russian rubles;

- In August, 28, 1993, during the occupation of Fizuli region, the doctor of an ambulance hospital, Shamsi Shixaliyev, was captured by Armenian servicemen. In March 27, 1995, he was sold to his brother for 8 thousand dollars ${ }^{21}$.

Most of the people killed in Armenian captivity: committed suicide because of the torture; died of illness; or were hidden by Armenians and used in heavy physical work in Armenia and

18 Resolutions of the 73rd session. http://www.un.org/en/ga/73/resolutions.shtml

19 UN General Assembly adopts resolution on missing persons prepared by Azerbaijan. 18 December, 2018. https:// report.az/en/foreign-politics/un-general-assembly-adopts-resolution-on-missing-persons-prepared-by-azerbaijan/

20 Erməni cinayətləri (sənədlər əsasında). Azərbaycan Respublikası Milli Təhlükəsizlik Nazirliyi. I c., Bakı: Vətən, 2004.

21 State Commission of the Republic of Azerbaijan on Prisoners of War, Hostages and Missing Persons. http:// human.gov.az/en/interviews/view/84/Armenian-Azerbaijan,_Nagorno-Karabakh_conflict_in_the_context_of_ international_humanitarian_law. 
the occupied Azerbaijani territories. According to investigations, it was possible to identify that 553 Azerbaijan citizens had been killed during Armenian captivity. Moreover, during the medical examination of the people which were liberated from Armenian captivity the experts found infectious diseases ${ }^{22}$. According to the Geneva Conventions of August 12, 1949, prisoners of war must be kept in a government that is not hostile, must not be held in separate homes or in military units in which they have been captured, should always be treated humanely, and no prisoner of war shall be subjected to physical torture or be the object of experiments ${ }^{23}$. International organizations with the opportunity to meet prisoners have limited their activities to technical missions only.

\section{Khojaly genocide}

Armenia's armed groups committed genocide in more than 30 settlements in the mountainous part of Karabakh, including Meshali, Jamilli, Tug, Imarat-Garvend, Sikhanvend, Umudlu, Karkijahan and other strategic settlements in June-December 1991. The Garadaghly, Gaibali, Malibeyli, Ashaghi Gushchular, Yukhari Gushchular villages were occupied and burned in January-February $1992^{24}$. Armenians killed 33 residents of Garadaghly. Then, they threw the bodies into the nearby silage well and buried them. The testimony of an eyewitness: "Five km to Khankendy, they had pulled all people down from the truck and undressed all warm clothes. They on foot brought us to Khankendy. Along the way, civilian Armenians threw stones at us and spat" ${ }^{25}$. Hundreds of Azerbaijanis were murdered, captured, or injured. The massive tragedy of the century - the Khojaly genocide was committed on the night of February 2526. Armenian Armed Forces slaughtered the Khojaly people with 10 tanks, 16 armored PDM (pedestrian combat vehicle), 180 soldiers and many soldiers of the 366th motorized regiment, included in the 23rd division of the 4th Army of the former USSR located in Khankendi. The Armenians completely destroyed Khojaly ${ }^{26}$. During the occupation of Khojaly 613 people were brutally tortured: 63 of them were minors; 106 were women of varying ages; and 70 were old people. Four hundred eighty-seven of these people were disabled: Of these, 76 were children. One thousand, two-hundred, seventy-five people were captured; eight families were killed; the city was burned; 25 children lost both parents; and 130 children lost one parent. According to the data of October 1st 2016,186 people were missing, 31 of them children (11 girls), 59 women, 13 old men and 20 old Women. Of the 186 missing persons, 95 were witnesses of

22 State Commission of the Republic of Azerbaijan on Prisoners of War, Hostages and Missing Persons.

23 The Geneva conventions of 12 august 1949. International Commite of the Red Cross. https://www.icrc.org/en/ doc/assets/files/publications/icrc-002-0173.pdf; Международное право [International Law]: Учебник / Отв. ред. Колосов Ю.М., Кузнецов В.И. М.: Международные отнощения, 1998, 357.

24 Xocalı yaddaşı. Bakı: Azərbaycanda Vətəndaş Cəmiyyətinin İnkişafına Yardım Assosiasiyası. 2017, 32.

25 State Commission of the Republic of Azerbaijan on Prisoners of War, Hostages and Missing Persons. (The testimony of Tagiyev Tevon Habib oglu, 24.05.2003).

26 Həsənov Ә. Azərbaycanlılara qarşı həyata keçirilən Xocalı soyqırımı və onun beynəlxalq əks-sədası. http:// justiceforkhojaly.org/sites/default/files/publication/Ali\%20Hasanov\%20doc.-\%20Khojaly.pdf, 4 
being captured and taken hostage by the Armenians. Among those 95 people there were 12 children (two girls), 23 women, four old men and seven women ${ }^{27}$.

The second tabor of the $366^{\text {th }}$ regiment under the command of an Armenian officer, Major Oganyan Seyran Mushegovih, the $3^{\text {rd }}$ tabor under the command of Yevgeni Nabokichin, Headquarter Chief of the $1^{\text {st }}$ tabor, Chitchyan Valery Isayevich, and more than 50 Armenian officers and soldiers participated in the attack on Khojaly ${ }^{28}$.

The people in Khojaly were killed with special brutality. As a result of forensic examination of 181 corpses in Aghdam, 20 were killed by scalping, 151 were shot, and ten people died by blunt instrument, thirteen of those examined were children ${ }^{29}$. The Khojaly genocide was directly implemented by the Armenian government. In an interview with British writer and journalist, Thomas de Waal (a specialist on the Nagorno-Karabakh conflict), Serzh Sargsyan, admitted that Azerbaijani civilians had been killed but claimed that there were exaggerations and stated the following regarding the Khojali Massacre (deemed by Azerbaijanis to constitute a genocide):"Before Khojalu [Khojali], the Azerbaijanis thought that they were joking with us, they thought that the Armenians were people who could not raise their hand against the civilian population. We needed to put a stop to all that. And that's what happened. ."30

According to the report of the human rights center of Russia "Memorial", there was a fact recorded about the scalping of a live human ${ }^{31}$. The magazine "Le Monde" in Paris stated on 14 March 1992: “...Reporters in Agdam witnessed the head skin peeling and nail removal of three people among the killed children and women in Khojaly. These are not Azerbaijan propaganda, but reality..." 32 . The journal of "Izvestia" in Moscow, the "Krua L'Evaneman" magazine in Paris, the "Times" newspaper in London, the "Sandi Tayms" newspaper, the "Financial Times" newspaper, and the "Valer Aktyuel" magazine in Paris talked about the brutal killings of Armenians in Khojaly ${ }^{33}$. In a letter sent by the Azerbaijani Parliament to a non-governmental organization in the US, "Helsinki Watch" on 17 July 1992 wrote that 927 people were killed in Khojaly. A representative of the Helsinki Watch said that this information was available, but it was unclear whether these deaths occurred due to frostbite, bullet wounds, or some other cause $\mathrm{e}^{34}$. Many countries around the world, including about 20 US states,

27 State Commission of the Republic of Azerbaijan on Prisoners of War, Hostages and Missing Persons. http:// www.human.gov.az/en/view-page/34/Xocal

28 State Commission of the Republic of Azerbaijan on Prisoners of War, Hostages and Missing Persons. http:// www.human.gov.az/en/view page/34/Xocal

29 Xocalı yaddaşı. Bakı: Azərbaycanda Vətəndaş Cəmiyyətinin İnkişafına Yardım Assosiasiyası. 2017, 169; Xocalı soyqırımı rabitəçilərin yaddaşında. Bakı, 2009, 25; Məmmədova H. Xocalı: Şəhidlər, Şahidlər. Bakı: "Yeni nəşrlər evi", 2003, 19.

30 Thomas de Waal, "A President, an Interview, and a Tragic Anniversary," Carnegie Endowment for International Peace, February 24, 2012, http://carnegieendowment.org/2012/02/24/president-interviewand-tragicanniversary/9vpa

31 Xocalı soyqırımı rabitəçilərin yaddaşında..., 25.

32 Xocalı soyqırımı rabitəçilərin yaddaşında...., 22-23.

33 Xocalı soyqırımı rabitəçilərin yaddaşında....., 20-24.

34 Xocalı yaddaşı......, 171. 
Mexico, Colombia, Pakistan, Jordan, Panama, Honduras and Sudan recognize and condemn the Khojaly genocide ${ }^{35}$. The Czech Republic was the first country to recognize the Khojaly massacre among members of the European Union and recognized these acts as a crime against humanity. The Czech Republic adopted a resolution on this on February 7, $2013^{36}$. Eventually, on February 26, 2013 Bosnia and Herzegovina adopted a resolution on the "Recognition and respect for sovereignty and territorial integrity of the Republic of Azerbaijan" ${ }^{37}$. The Foreign Ministers of the Organization of Islamic Cooperation also adopted a resolution to assess the Khojaly tragedy as a massacre. In July 2009, an agreement was achieved between the OIC Youth Forum and ISESCO on the Khojaly genocide to be included in the history textbooks of Organization of Islamic Cooperation countries ${ }^{38}$. The Khojaly tragedy was first known as a genocide act during the $39^{\text {th }}$ session of the Council of Foreign Ministers of the Organization of Islamic Cooperation in Djibouti on November 15-17, $2012^{39}$.

According to international law, genocide crimes are considered the most serious crimes against humanity. Taking into consideration the need for international co-operation to prevent genocide that has caused great losses to humanity, the UN General Assembly adopted the Convention on the Prevention and Punishment of the Crime of Genocide on 9 December 1948. This convention contains genocide accusations. While occupying Azerbaijani lands, the Armenian armed forces repeatedly committed genocide against Azerbaijanis and applied all the acts of genocide that were found in the convention against the Azerbaijanis. The General Assembly's resolution of 3 December 1973 outlined the principles of international cooperation in the detection, arrest, extradition, and punishment of persons guilty of war crimes and crimes against humanity ${ }^{40}$. Article 1 of the resolution states that military offenses and crimes against humanity should be investigated regardless of when and where they are committed, and those who have evidence of committing such crimes should be prosecuted and punished as guilty. It is said there: "War crimes and crimes against humanity, wherever they are committed, shall be subject to investigation and the persons against whom there is evidence that they have committed such crimes shall be subject to tracing, arrest, trial and, if found guilty, to punishment" ${ }^{41}$. According to Article 5, persons against whom there is evidence that they have committed war crimes and crimes against humanity shall be subject to trial and, if found guilty, punished, as a general rule in the countries in which they committed those crimes. In

35 Həsənov Ә. Azərbaycanlılara qarşı həyata keçirilən Xocalı soyqırımı və onun beynəlxalq əks-sədası. http:// justiceforkhojaly.org/sites/default/files/publication/Ali\%20Hasanov\%20doc.-\%20Khojaly.pdf, 10-11.

36 Həsənov Ә.Azərbaycanlılara qarşı həyata keçirilən Xocalı soyqııımı və onun beynəlxalq əks-sədası....., 11.

37 Həsənov Ә.Azərbaycanlılara qarşı həyata keçirilən Xocalı soyqııımı və onun beynəlxalq əks-sədası....., 12.

38 Həsənov Ә.Azərbaycanlılara qarşı həyata keçirilən Xocalı soyqırımı və onun beynəlxalq əks-sədası....., 6 .

39 Həsənov Ә.Azərbaycanlılara qarşı həyata keçirilən Xocalı soyqırımı və onun beynəlxalq əks-sədası......, 7.

40 Principles of international co-operation in the detection, arrest, extradition and punishment of persons guilty of war crimes and crimes against humanity. Adopted by General Assembly resolution 3074 (XXVIII) of 3 December 1973. http://www.ohchr.org/EN/Professional Interest/Pages/PersonsGuilty.aspx

41 Principles of international co-operation in the detection, arrest, extradition and punishment of persons guilty of war crimes and crimes against humanity....... 
that connection, States shall co-operate on questions of extraditing such persons ${ }^{42}$. There are the following international norms of law and treaties to be applied to the crimes committed against Khojaly as genocide: The Convention on the Prevention and Punishment of the Crime of Genocide ${ }^{43}$, adopted by the General Assembly of the United Nations on 9 December 1948; Charter of Nuremberg Military Tribunals on August 194544; Article 4 of the Statute of the International Criminal Tribunal for the former Yugoslavia ${ }^{45}$; Article 1 of the Statute of the International Tribunal for Rwanda ${ }^{46}$; Article 6 of the International Criminal Court Statute; ${ }^{47}$ Article 103 of the Criminal Code of the Republic of Azerbaijan; ${ }^{48}$ Decree of the President of the Republic of Azerbaijan on the genocide of the Azerbaijani people ${ }^{49}$.

Taking into account these international law documents, genocide is a crime, which provides the following legal consequences: a) The prosecution and punishment of those who committed genocide are inevitable. (b) The offense is not merely an act of genocide, it is also a direct and open-minded act of assassination, direct and explicit provocation of genocide, an attempt to commit genocide and commitment of genocide. c) The principles of universal jurisdiction should apply to those who committed genocide. (d) When committing a genocide, reference to the execution of the order does not relieve it of responsibility. (e) Leaders are responsible for not performing acts to prevent genocide. f) An extradition period for criminal offenses is not applied to genocide crimes. g) The retroactive application of the law in respect of the crime of genocide shall be permitted. 1) Persons who committed genocide must be brought to the country requiring criminal prosecution. The International Court should recognize the Khojaly genocide as genocide.

\section{Armenia violates international law on captives and hostages}

Armenia, which is participant of The International Covenant on Civil and Political Rights, The International Covenant on Economic, Social and Cultural Rights, The Convention on the Prevention and Punishment of the Crime of Genocide, The Convention on the Elimination of All Forms of Racial Discrimination, The Convention on the Rights of the Child and The

42 Principles of international co-operation in the detection, arrest, extradition and punishment of persons guilty of war crimes and crimes against humanity.

43 Convention on the Prevention and Punishment of the Crime of Genocide. Adopted by the General Assembly of the United Nations on 9 December 1948. https://treaties.un.org/doc/publication/unts/volume\%2078/volume78-i-1021-english.pdf

44 Agrement for the prosecution and punishment of the major war criminals of the European Axis. Signed at London, on 8 August 1945. http://www.un.org/en/genocideprevention/documents/atrocity-crimes/Doc.2_Charter\%20 of\%20IMT\%201945.pdf

45 Updated Statute of the International Criminal Tribunal for the former Yugoslavia. http://www.icty.org/x/file/ Legal\%20Library/Statute/statute_sept09_en.pdf

46 Statute of the International Tribunal for Rwanda. http://legal.un.org/avl/pdf/ha/ictr_EF.pdf

47 Rome Statute of the International Criminal Court. http://legal.un.org/icc/statute/99_corr/cstatute.htm

48 Criminal Code of the Azerbaijan Republic https:/www.wipo.int/edocs/lexdocs/laws/en/az/az017en.pdf

49 Decree of the President of the Republic of Azerbaijan on the genocide of the Azerbaijani people http://www. qmkdk.gov.az/en/laws/84.html 
Convention on the Elimination of All Forms of Discrimination against Women, The Convention against Torture and other Cruel, Inhuman or Degrading Treatment or Punishment adopted by the General Assembly of the United Nations on 10 December 1984, The European Convention for the Protection of Human Rights and Fundamental Freedoms, has not fulfilled its obligations from international law ${ }^{50}$. Azerbaijan has taken action in accordance with the resolution of the UN General Assembly on 14 December 1974 about the immediate release of women and children held hostage in the armed conflict, the Final Document of the 4th World Conference on Women held in Beijing on September 15, 1995, the final and action platform for the documents of the 23rd General Assembly, Geneva Conventions of 12 August 1949, relevant resolutions of the General Assembly and the Commission on Human Rights. Article 1 of the Declaration on the Protection of Women and Children in Emergency and Armed Conflict proclaimed by General Assembly resolution 3318 (XXIX) of 14 December 1974 states that attacks, bombings which causes harm to innocent civilians, particularly women and children who are the most defenseless, are prohibited and such actions must be condemned ${ }^{51}$. According to Article 5, all forms of repression and cruel and inhuman treatment of women and children, including imprisonment, torture, shooting, mass arrests, collective punishment, destruction of dwellings and forcible eviction, committed by belligerents in the course of military operations or in occupied territories shall be considered criminal ${ }^{52}$.

By the insistence of the Azerbaijani delegation the following content was included in the Final Document of the 4th World Conference on Women in Beijing: "Hostage of women during military conflicts is one of the forms of violence against women"53.

In addition, Armenia violated the 1989 Convention on the Rights of the Child. Dozens of children were captured during the occupation of Azerbaijani lands and are detained in Armenia. During all armed conflicts and military operations, all possible efforts should be made to keep the integrity of families and prevent their destruction. According to Article 26 of the Geneva Convention, parties should facilitate searches by members of disenfranchised families in identifying relationships and ensuring their merger ${ }^{54}$. As a result of Armenia's military aggression against Azerbaijan, 195 Azerbaijani children were killed by Armenian armed forces. Of the 216 Azerbaijanis that were killed in the 1988-1989 ethnic cleansing more than 250,000 Azerbaijanis, 23 of them were children. Eyewitnesses say the number of children killed was even greater. On December 5, 1988, Armenians put 17 young children into

50 Сборник документов ООН по армяно-азербайджанскому нагорно-карабахскому конфликту [UN's Documents on the Armenian-Azerbaijani Nagorno-Karabakh Conflict]......, 357.

51 İnsan hüquqlar1-Beynəlxalq müqavilələr toplusu, Bak1: Azərbaycan, 1998, 290.

52 Declaration on the Protection of Women and Children in Emergency and Armed Conflict. P.2. http://www. un.org/en/genocideprevention/documents/atrocity-crimes/Doc. 19 declaration\%20protection\%20women $\% 20$ armed\%20conflict.pdf; İnsan hüquqlar1-Beynəlxalq müqavilələr toplusu, Bakı: Azərbaycan, 1998, 290.

53 Azərbaycan BMT ailəsində. Bak1, 2000, 333.

54 The Geneva Conventions of 12 August 1949. https://www.icrc.org/en/doc/assets/files/publications/icrc-0020173.pdf, 44. 
a large-scale pipe in Hamamli City (Spitak), welding both sides. They threw the pipe off of a tall cliff into a valley killing all of them. In November of that same year, about 70 children aged between 5 and 12 years in Gukark (Garakilse-Pambak region) were put in a pipe and brutally murdered by closing both sides. The massacre was revealed in December 1988 by French rescuers who came to help with the earthquake in Armenia ${ }^{55}$.

From 1988-1994, Armenian terrorist groups and armed groups captured thousands of Azerbaijani children. Some were brutally killed, some wounded, and some went missing. Fifty-three of the four thousand five hundred sixty-six missing Azerbaijanis in those years were children. According to a report on January 1, 2014, twenty-two children of eight hundred seventy-seven people captured and taken hostage are still in Armenia today. Armenia refuses to return peaceful residents, including children and women, who are captured in defiance of international law. Armenian armed forces tortured people captured and taken hostage by them. The Ministry of Foreign Affairs of the Republic of Azerbaijan indicates that approximately three hundred Azerbaijani captives and twenty-three hostages were shot in the camp near Spitak. The Press Service of the Ministry of Foreign Affairs of Armenia acknowledged that eight Azerbaijani captives were shot because they tried to escape ${ }^{56}$. The Ministry of Foreign Affairs of the Republic of Azerbaijan called the international community, the International Committee of the Red Cross (ICRC) and other international humanitarian organizations to investigate criminal cases taking into account that the Armenian government violated rights of unprotected victims of war treating them inhumanely, and not achieving any result from investigations for crimes committed by Armenians in opposition to Geneva Conventions of 12 August 194957. On 23 March, 1993, by the initiative of the ICRC, Azerbaijan received ten corpses. Healthcare authorities of Azerbaijan and the independent expert doctor Derek Paundor, a member of International Academy Presidium of juridical and social medicine and a member of the British organization "Physicians for human rights"confirmed that these were the remains of military captives who had been shot ${ }^{58}$. Researchers of the Forensic Medical Examination Commission of the Ministry of Health of Azerbaijan, rejected the report of the Ministry of the Foreign Affairs of Armenia's Press Service, by showing that the captives were beaten and exposed to torture prior to being killed. Millitary captives, R. R. Agayev, E. G.

55 Dadaşova R.B. "Ermenistan'in Azerbaycana karşi askeri saldirisi zamani çocuk haklari maruziyeti”. II Uluslararası Türk dünyası eğitim bilimleri ve sosyal bilimler kongresi. 6.cild, Sosyal beşeri ve idari bilimleri-2 Ankara, 2018, 161.

56 Письмо представителя Азербайджана от 21 февраля 1994 года на имя Генерального секретаря, Документ S/1994/206[Letter dated 21 February 1994 from the representative of Azerbaijan addressed to the SecretaryGeneral, Document S / 1994/206], Совет Безопасности. Официальнее отчеты сорок девятый год дополнение за январь, февраль, март 1994 года, Организация Объединенных Наций, Нью-Йорк, 1997, 168-169.

57 Ibid.

58 Письмо представителя Азербайджана от 26 апреля 1994 года на имя Генерального секретаря, Документ S/1994/505 [Letter dated 26 April 1994 from the representative of Azerbaijan addressed to the Secretary-General, Document S / 1994/505], Совет Безопасности. Официальнее отчеты сорок девятый год дополнение за апрель, май, июнь 1994 года, Организация Объединенных Наций, Нью-Йорк, 1998, 117. 
Ahmadov, E. S. Mammadov, G. K. Mammadov, F. G. Guliyev, E. M. Ahmadov were shot from the gut, B. A. Giyasov was shot from the chest from a distance. R. R. Agayev, E. G. Ahmadov, and E. S. Mammadov's ears were cut off. Also the internal organs of R. R. Agayev - heart, liver, and spleen were removed. On the remains of I.S. Nasirov, there were signs of odor proving extended periods of starvation. On the remains of F.G. Huseynov many signs of torture were observed ${ }^{59}$.

Russian and United States' human rights organizations, including the New York Times, claim that human rights violations have been violated in the course of the Armenian-Azerbaijani Nagorno-Karabakh conflict, they witnessed corpses with their head cut off, head skin removed, and the skin of one person's head was removed while he was alive ${ }^{60}$. Referring to the mentioned sources, a United States congressman made a speech at the House of Representatives and urged congressmen to recognize the Khojaly genocide. Deputy Berton said that Armenians perceived what they did in Khojaly as a tactical step to the end of the war ${ }^{61}$.

The UN representatives also witnessed brutal torture applied to hostages and captives in Armenia. For example, the UN representative in Baku, Mahmoud Al-Said, was shown an Azerbaijani civilian's remains. This man was exposed to torture and brutality during his captivity, his fingers were removed by rope, and his chest was cauterized by a cigarette. This fact was confirmed by Mahmoud Al-Said ${ }^{62}$.

In accordance with the cease-fire agreement that was signed on May 12, 1994, Armenia had to stop the attack on Azerbaijani lands. The agreement encouraged the urgent release of captives, the exchange of war prisoners by mediation of ICRC or other international organizations ${ }^{63}$. The conflicting parties had to inform each other and the OSCE observers on the disaster tools set up in the mined areas and districts ${ }^{64}$. However, Armenia did not just violate the ceasefire agreement but continued to violate human rights, including the rights of prisoners and

59 Письмо представителя Азербайджана от 1 апреля 1994 года на имя Генерального секретаря, Документ S/1994/393[Letter dated 1 April 1994 from the representative of Azerbaijan addressed to the Secretary-General, Document S / 1994/393], Совет Безопасности. Официальнее отчеты сорок девятый год дополнение за апрель, май, июнь 1994 года, Организация Объединенных Наций, Нью-Йорк, 1998, 15.

60 Письмо постоянного представителя Азербайджана при Организаций Объединенных Наций от 24 февраля 2005 года на имя Генерального секретаря [Letter dated 24 February 2005 from the Permanent Representative of Azerbaijan to the United Nations addressed to the Secretary-General] // Diplomatiya Aləmi Jurnal1, 2005, №10, 37-38.

61 Ibid.

62 Письмо представителя Азербайджана от 15 августа 1993 года на имя Председателя Совета Безопасности, Документ S/26307 [Letter dated 15 August 1993 from the representative of Azerbaijan addressed to the President of the Security Council, Document S / 26307], Совет Безопасности. Официальнее отчеты сорок восьмой год дополнение за июль, август, сентябрь 1993 года, Организация Объединенных Наций, Нью-Йорк, $1995,210$.

63 Письмо представителя Швеции от 9 июня 1994 года на имя Председателя Совета Безопасности, Документ S/1994/687[Letter dated 9 June 1994 from the representative of Sweden addressed to the President of the Security Council, Document S / 1994/687], Совет Безопасности. Официальнее отчеты сорок девятый год дополнение за апрель, май, июнь 1994 года, Организация Объединенных Наций, Нью-Йорк, 1998, 376-378.

64 Ibid. 
hostages. Armenia committed offences under the International Convention Against the Taking of Hostages adopted by the General Assembly of the United Nations on 17 December 1979. As reported in Article 2 of this Convention "Each State Party shall make the offences set forth in article 1 punishable by appropriate penalties which take into account the grave nature of those offences" $"$. Article 1 states: "Any person who seizes or detains and threatens to kill, to injure or to continue to detain another person (hereinafter referred to as the "hostage") in order to compel a third party. namely, a State, an international intergovernmental organization, a natural or Juridical person, or a group or persons, to do or abstain from doing any act as an explicit or implicit condition for the release of the hostage commits the offence or taking of hostages ("hostage-taking") within the meaning of this Convention" ${ }^{\text {"6 }}$. The Armenian armed forces ignored the cease-fire and even have recently taken innocent civilians as captives. On July 11, 2014, Russian citizen, Dilgam Asgarov, and Azerbaijani citizen, Shahbaz Guliyev, were taken by Armenian armed forces while visiting the graves of their relatives in Shaplar village of the Kalbajar region. A third Azerbaijani citizen, Hasan Hasanov, was killed. An unlawful court in the occupied Nagorno Karabakh was set up, and the court sentenced D. Asgarov to life in prison and S. Guliyev was sentenced to 22 years in prison ${ }^{67}$.

\section{Conclusion}

Summarizing the above studies, it can be concluded that compliance with the principle of human rights protection is one of the main factors affecting the settlement of international conflicts.

In 2004, Azerbaijan was represented at a high level in the United Nations structures, and the Permanent Delegation of Azerbaijan in the UN was elected vice president of the Economic and Social Council and United Nations General Assembly. Because of the serious efforts of the Azerbaijani delegation, resolutions were adopted on the situation of women and children taken hostage in the conflict, and the situation of missing persons. In 2006, a new body, the Human Rights Council was formed, Azerbaijan became a member of the Council and had the opportunity to convey the real truth about the allegations of Armenians to the world community. On 17 December 2018, with the initiative of Azerbaijan, the Resolution on Missing Persons A/ RES/73/178 was adopted through consensus at the plenary session of the UN General Assembly. What measures can the world community take against the fact that Armenia will not comply with international law in relation to captives and hostages? First, as a universal organization that sets the principle of respect for human rights and fundamental freedoms, the UN Security Council can force Armenia to comply with international humanitarian law. Second, referring to

65 International Convention Against the Taking of Hostages. Adopted by the General Assembly of the United Nations on 17 December 1979. https://treaties.un.org/doc/db/terrorism/english-18-5.pdf

66 Ibid.

67 BQXK əməkdaşları Dilqəm Đsgərov və Şahbaz Quliyevlə görüşüblər 03.11.2016. http://kaspi.az/az/bqxkemekdaslari-dilqem-esgerov-ve-sahbaz-quliyevle-grusubler/pages/q.pdf 
resolutions adopted by the UN Security Council, the International Criminal Tribunal for Khojaly should be established and criminals should be punished. In order to prevent similar tragedies, those who are guilty of the Khojaly genocide and other tragedies must be held into account. Thirdly, the International Court of Justice Commission can be established to regulate legal matters concerning prisoners. The International Court of Justice Commission should cooperate closely with the International Court of Justice, the Human Rights Council, the Compensation Commission, and conduct joint investigations. Fourth, prisoners of war and hostages should be released, criminals should be punished according to the outcome of investigations.

Peer-review: Externally peer-reviewed.

Conflict of Interest: The author has no conflict of interest to declare.

Grant Support: The author declared that this study has received no financial support.

Hakem Değerlendirmesi: Dış bağımsız.

Çıkar Çatışması: Yazar çıkar çatışması bildirmemiştir.

Finansal Destek: Yazar bu çalışma için finansal destek almadığını beyan etmiştir.

\section{References}

Agrement for the prosecution and punishment of the major war criminals of the European Axis. Signed at London, on 8 August 1945. http://www.un.org/en/genocideprevention/documents/atrocity-crimes/ Doc.2_Charter\%20of\%20IMT\%201945.pdf

Azarbaycan BMT ailasində. Bak1, 2000.

BQXK əməkdaşları Dilqəm Đsgərov və Şahbaz Quliyevlə görüşüblər 03.11.2016. http://kaspi.az/az/bqxkemekdaslari-dilqem-esgerov-ve-sahbaz-quliyevle-grusubler/pages/q.pdf

Charter of the United Nations and Statute of the İnternational Court of Justice. San Francisco, 1945. https:// treaties.un.org/doc/publication/ctc/uncharter.pdf

Conference on Security and Cooperation in Europe Final Akt. Helsinki, 1975. http://www.osce.org/helsinkifinal-act?download=true

Convention on the Prevention and Punishment of the Crime of Genocide. Adopted by the General Assembly of the United Nations on 9 December 1948. https://reaties.un.org/doc/publication/unts/volume\%2078/ volume-78-i-1021-english.pdf

Criminal Code of the Azerbaijan Republic https://www.wipo.int/edocs/lexdocs/laws/en/az/az017en.pdf

DADAŞOVA R.B. "Ermenistan'in Azerbaycana karşı askeri saldırısı zamanı çocuk Hakları maruziyeti”. II Uluslararası Türk dünyası eğitim bilimleri ve sosyal bilimler kongresi. 6.cild, Sosyal beşeri ve idari bilimleri-2 Ankara, 2018. s.159-166.

Declaration on the Protection of Women and Children in Emergency and Armed Conflict. http://www.un.org/ en/genocideprevention/documents/atrocity-crimes/Doc.19_declaration\%20protection $\% 20$ women $\% 20$ armed\%20conflict.pdf; İnsan hüquqları-Beynəlxalq müqavilələr toplusu, Bakı: Azərbaycan, 1998.

Decree of the President of the Republic of Azerbaijan on the genocide of the Azerbaijani people http://www. qmkdk.gov.az/en/laws/84.html 
Erməni cinayətləri (sənədlər əsasında). Azərbaycan Respublikası Milli Təhlükəsizlik Nazirliyi. I c., Bakı: Vətən, 2004.

European Convention on Human Rights, http://swww.echr.coe.int/Documents/Convention_ENG.pdf

Fact Sheet: A summary of the rights under the Convention on the Rights of the Child. https://www.unicef.org/ crc/files/Rights_overview.pdf

HəSəNOV Ә. Azərbaycanlılara qarşı həyata keçirilan Xocalı soyqırımı va onun beynəlxalq əks-sadası. http:// justiceforkhojaly.org/sites/default/files/publication/Ali\%20Hasanov\%20doc.-\%20Khojaly.pdf

Insan hüquqları-Beynalxalq müqavilalar toplusu, Bakı: Azərbaycan, 1998.

International Convention Against the Taking of Hostages. Adopted by the General Assembly of the United Nations on 17 December 1979. https://treaties.un.org/doc/db/terrorism/english-18-5.pdf

IV Geneva Convention relative to the protection of civilian persons in time of war of 12 august 1949.http:// www.un.org/en/genocideprevention/documents/atrocity-crimes/Doc.33_GC-IV-EN.pdf

MӘMМӘDOVA H. Xocalı: Şəhidlər, Şahidlər. Bakı: "Yeni nəşrlər evi”, 2003.

Participation in International Humanitarian Law Treaties and Their National Implementation. Achievements and activities in the countries of the Americas in 2005. Document prepared by the International Committee of the Red Cross (ICRC) for the information of the Member States of the Organization of American States. January, 2006. https://www.icrc.org/en/doc/assets/files/other/informe_202005_eng.pdf, 36 p.

Principles of international co-operation in the detection, arrest, extradition and punishment of persons guilty of war crimes and crimes against humanity. Adopted by General Assembly resolution 3074 (XXVIII) of 3 December 1973. http://www.ohchr.org/EN/Professional Interest/Pages/PersonsGuilty.aspx

Protocol Additional to the Geneva Conventions of 12 august 1949, and relating to the Protection of victims of international armed conflicts (protocol I), of 8 june 1977. https://www.icrc.org/en/doc/assets/files/other/ icrc_002_0321.pdf

Resolution adopted by General Assembly 61/155, http://mfa.gov.az/files/file/UN

Resolution adopted by General Assembly 63/183. http://mfa.gov.az/files/file/UN

Resolutions of the 73rd session. http://www.un.org/en/ga/73/resolutions.shtml

Rome Statute of the International Criminal Court. http://legal.un.org/icc/statute/99_corr/cstatute.htm

State Commission of the Republic of Azerbaijan on Prisoners of War, Hostages and Missing Persons. http:// www.human.gov.az/en/

Statute of the International Tribunal for Rwanda. http://legal.un.org/avl/pdf/ha/ictr_EF.pdf

The Geneva conventions of 12 august 1949. International Commite of the Red Cross. https://www.icrc.org/ en/doc/assets/files/publications/icrc-002-0173.pdf

The Geneva Conventions of 12 August 1949. IV Geneva Convention relative to the Protection of Civilian Persons in Time of War. Geneva, International Committee of the Red Cross 1958

The Universal Declaration of Human Rights http://www.un.org/en/udhrbook/pdf/udhr_booklet_en_web.pdf

THOMAS de Waal, "A President, an Interview, and a Tragic Anniversary," Carnegie Endowment for International Peace, February 24, 2012, http://carnegieendowment.org/2012/02/24/president-interviewand-tragicanniversary $/ 9 \mathrm{vpa}$ 
UN General Assembly adopts resolution on missing persons prepared by Azerbaijan. 18 December, 2018. https://report.az/en/foreign-politics/un-general-assembly-adopts-resolution-on-missing-persons-preparedby-azerbaijan/

Updated Statute of the International Criminal Tribunal for the former Yugoslavia. http:/www.icty.org/x/file/ Legal\%20Library/Statute/statute_sept09_en.pdf

Xocalı soyqurımı rabitaçilarin yaddaşında. Bakı, 2009.

Xocalı yaddaşı. Bakı: Azərbaycanda Vətəndaş Cəmiyyətinin İnkişafına Yardım Assosiasiyası. 2017.

Международное право [International Law]: Учебник / Отв.ред. Колосов Ю.М., Кузнецов В.И. М.: Международные отнощения, 1998.

Письмо представителя Азербайджана от 1 апреля 1994 года на имя Генерального секретаря, Документ S/1994/393 [Letter dated 1 April 1994 from the representative of Azerbaijan addressed to the SecretaryGeneral, Document S / 1994/393], Совет Безопасности. Официальнее отчеты сорок девятый год дополнение за апрель, май, июнь 1994 года, Организация Объединенных Наций, Нью-Йорк, 1998.

Письмо представителя Азербайджана от 15 августа 1993 года на имя Председателя Совета Безопасности, Документ S/26307 [Letter dated 15 August 1993 from the representative of Azerbaijan addressed to the President of the Security Council, Document S / 26307], Совет Безопасности. Официальнее отчеты сорок восьмой год дополнение за июль, август, сентябрь 1993 года, Организация Объединенных Наций, Нью-Йорк, 1995.

Письмо представителя Азербайджана от 21 февраля 1994 года на имя Генерального секретаря, Документ S/1994/206 [Letter dated 21 February 1994 from the representative of Azerbaijan addressed to the SecretaryGeneral, Document S / 1994/206], Совет Безопасности. Официальнее отчеты сорок девятый год дополнение за январь, февраль, март 1994 года, Организация Объединенных Наций, Нью-Йорк, 1997.

Письмо представителя Азербайджана от 26 апреля 1994 года на имя Генерального секретаря, Документ S/1994/505 [Letter dated 26 April 1994 from the representative of Azerbaijan addressed to the SecretaryGeneral, Document S / 1994/505], Совет Безопасности. Официальнее отчеты сорок девятый год дополнение за апрель, май, июнь 1994 года, Организация Объединенных Наций, Нью-Йорк, 1998.

Письмо представителя Швеции от 9 июня 1994 года на имя Председателя Совета Безопасности, Документ S/1994/687 [Letter dated 9 June 1994 from the representative of Sweden addressed to the President of the Security Council, Document S / 1994/687], Совет Безопасности. Официальнее отчеты сорок девятый год дополнение за апрель, май, июнь 1994 года, Организация Объединенных Наций, Нью-Йорк, 1998.

Письмо постоянного представителя Азербайджана при Организаций Объединенных Наций от 24 февраля 2005 года на имя Генерального секретаря [Letter dated 24 February 2005 from the Permanent Representative of Azerbaijan to the United Nations addressed to the Secretary-General] // Diplomatiya Aləmi Jurnal1, 2005, №10

Сборник документов ООН по армяно-азербайджанскому нагорно-карабахскому конфликту [UN's Documents on the Armenian-Azerbaijani Nagorno-Karabakh Conflict], Баку, Министерство Иностранных Дел, 2009. 
